\title{
OCENA POZIOMU WIEDZY STUDENTÓW PIELĘGNIARSTWA NA TEMAT CUKRZYCY TYPU II
}

\author{
ASSESSMENT OF NURSING STUDENTS' KNOWLEDGE ABOUT TYPE 2 DIABETES MELLITUS \\ Iwona Janeczek ${ }^{1}$, Małgorzata Machaj ${ }^{2}$, Mariusz Panczyk ${ }^{3}$, Zofia Sienkiewicz ${ }^{4}$, Joanna Gotlib ${ }^{2}$ \\ ${ }^{1}$ Wydział Nauki o Zdrowiu \\ Warszawski Uniwersytet Medyczny \\ ${ }^{2}$ Dział Organizacji i Zasobów Ludzkich CSK MSW w Warszawie \\ ${ }^{3}$ Zakład Dydaktyki i Efektów Kształcenia \\ Warszawski Uniwersytet Medyczny
}

DOI: https://doi.org/10.20883/pielpol.2017.26

\section{STRESZCZENIE}

Wstęp. Powikłania cukrzycy stanowią obecnie jedną z głównych przyczyn zgonów i inwalidztwa na świecie, dlatego też edukowanie pacjentów jest jednym z najważniejszych zadań pielęgniarki w opiece nad pacjentami z cukrzyca.

Cel. Celem pracy była próba oceny poziomu wiedzy studentów Warszawskiego Uniwersytetu Medycznego na temat cukrzycy typu II.

Materiał i metody. Badaniami objęto 101 studentów pielęgniarstwa Warszawskiego Uniwersytetu Medycznego. W pracy zastosowano metodę sondażu diagnostycznego - kwestionariusz ankiety własnej konstrukcji. Do obliczeń statystycznych wykorzystano test chi-kwadrat.

Wyniki. Większość studentów posiada ogólną wiedzę o cukrzycy, jednak nie jest ona wystarczająca do prawidłowej opieki i edukacji chorych z cukrzycą typu II. Niski jest poziom wiedzy dotyczącej wprowadzania insuliny do leczenia cukrzycy typu II oraz sposobu jej wstrzykiwania. Ponadto studenci pielęgniarstwa nie przywiązują istotnej uwagi do wpływu tytoniu i alkoholu na organizm osób chorych na cukrzycę.

Wnioski.

1. Studenci pielęgniarstwa posiadają ogólną wiedzę o czynnikach ryzyka choroby, a także o znaczeniu diety i stylu życia w jej leczeniu, jednakże szczegółowy poziom wiedzy o cukrzycy jest niewystarczający do realizacji prawidłowej opieki i edukacji pacjentów z cukrzycą typu II.

2. Różnicująco na poziom wiedzy wpływa posiadanie w rodzinie osoby chorej na cukrzycę.

3. Zaznacza się wyraźna potrzeba zwiększenia edukacji na rzecz cukrzycy w grupie studentów pielęgniarstwa.

SŁOWA KLUCZOWE: efekty kształcenia, studenci, pielęgniarstwo, cukrzyca typu II.

\section{Wstęp}

Cukrzyca, nazywana epidemią XXI wieku, jest chorobą przewlekłą. We współczesnym świecie jej powikłania stanowią główną przyczynę zgonów i inwalidztwa [1]. Niezwykle ważnym problemem w tej chorobie jest mi-

\begin{abstract}
Background. Complications of diabetes mellitus constitute one of the main causes of death and invalidity worldwide. Therefore, providing patients with necessary information is one of the key tasks of nurses taking care of patients with diabetes.

Aim. The study attempted to assess the knowledge level of Warsaw Medical University students about type 2 diabetes mellitus. Materials and methods. The study enrolled a total of 101 Nursing students of Warsaw Medical University. A diagnostic survey (a questionnaire developed by the authors) was used in the study. Chi-square test (Statistica 12.5) was used for statistical analyses. Results. Most students had general knowledge of diabetes but it was not sufficient to provide patients with type 2 diabetes mellitus with proper care and information. Knowledge of insulin adition to treatment of T2DM and methods of insulin injection was low. Moreover, Nursing students did not pay particular attention to the influence of tobacco and alcohol on patients with diabetes.

Conclusions

1. Although Nursing students had general knowledge of risk factors for diabetes mellitus as well as of the importance of diet and lifestyle in treatment of the disease, their detailed knowledge of diabetes was insufficient to provide proper care and information to patients with type 2 diabetes.

2. Having a family history of diabetes was a discriminatory factor.

3. There is a significant need to improve diabetes-related education among Nursing students.
\end{abstract}

KEYWORDS: outcomes of education, students, Nursing, type 2 diabetes mellitus

nimalizacja skutków i niedopuszczanie do powstawania powikłań [2]. Jest to jednak możliwe wyłącznie w przypadku wysokiego stopnia edukacji chorych, gdyż w tej chorobie wyniki leczenia zależą do trybu życia pacjenta [3]. 


\section{Cel pracy}

Celem pracy była próba oceny poziomu wiedzy studentów pielęgniarstwa Wydziału Nauki o Zdrowiu Warszawskiego Uniwersytetu Medycznego na temat cukrzycy typu II.

\section{Materiał}

W badaniach udział wzięło łącznie 101 studentów pielęgniarstwa (93 kobiet, 8 mężczyzn). Najliczniejszą grupę wiekową stanowiły osoby w wieku 30-39 lat. Większość badanych studentów zamieszkuje w dużym mieście (powyżej 20 tysięcy mieszkańców) i nie spotkało się dotychczas z problemem cukrzycy w najbliższym otoczeniu. Dodatkowo zapytano również o pokrewieństwo z osobą chorą na cukrzycę. Założono bowiem, że ta zmienna może wpływać na poziom wiedzy badanych na temat cukrzycy (Tabela 1).

Tabela 1. Charakterystyka grupy badanej Table 1. Characteristics of the study group

\begin{tabular}{|c|c|c|c|}
\hline Cecha badana/Feature & $\begin{array}{c}\text { Charakterystyka } \\
\text { badanej cechy/ } \\
\text { Characteristics of the feature }\end{array}$ & $\mathrm{n}$ & $\%$ \\
\hline \multirow{2}{*}{ Płeć/Gender } & Kobieta/Woman & 93 & 92,1 \\
\hline & Mężczyzna/Man & 8 & 7,1 \\
\hline \multirow{4}{*}{ Wiek/Age } & 20-29 lat/years of age & 26 & 25,7 \\
\hline & 30-39 lat/years of age & 31 & 30,7 \\
\hline & $40-49$ lat/years of age & 28 & 27,7 \\
\hline & 50-59 lat/years of age & 16 & 15,8 \\
\hline \multirow{5}{*}{$\begin{array}{l}\text { Miejsce zamieszkania/ } \\
\text { Place of residence }\end{array}$} & Wieś/Village & 23 & 22,8 \\
\hline & $\begin{array}{c}\text { Miasto }<5 \text { tys. mieszkańców/ } \\
\text { Town }<5,000 \text { inhabitants }\end{array}$ & 9 & 8,9 \\
\hline & Miasto 5-20 tys. miesz- & & \\
\hline & $\begin{array}{c}\text { kancow/ } \\
\text { Town of 5,000-20,000 } \\
\text { inhabitants }\end{array}$ & 14 & 15,9 \\
\hline & $\begin{array}{c}\text { Miast }>20 \text { tys. mieszkańców/ } \\
\text { Town >20,000 inhabitants }\end{array}$ & 55 & 54,5 \\
\hline \multirow{3}{*}{$\begin{array}{l}\text { Posiadanie osoby chorej } \\
\text { w najbliższym otoczeniu/ } \\
\text { Family history of diabetes } \\
\text { mellitus }\end{array}$} & Tak/Yes & 26 & 25,7 \\
\hline & $\mathrm{Nie} / \mathrm{No}$ & 75 & 74,3 \\
\hline & Nie wiem/l don't know & 0 & 0 \\
\hline
\end{tabular}

Źródło: opracowanie własne

Source: author's own analysis

\section{Metody}

Badania prowadzono metodą sondażu diagnostycznego, za pomocą kwestionariusza ankiety własnej konstrukcji, składającego się z 37 pytań, które uzupełniono metryczką. Pytania metryczkowe dotyczyły płci, wieku, miejsca zamieszkania oraz roku studiów osób badanych. W celu omówienia poziomu wiedzy studentów pielęgniarstwa przeprowadzono analizę statystyczną wyników uzyskanych w badaniach ankietowych. Wykorzystano do obliczeń nieparametryczny test statystyczny chi-kwadrat. Przyjęto, że różnica jest statystycznie istotna przy poziomie istotności $\alpha<0,05$.

\section{Wyniki}

Przeprowadzone badania wykazały, że posiadanie w rodzinie osoby chorej na cukrzycę typu II stanowi zmienną bardzo istotnie modyfikującą wiedzę badanych na temat poziomów glikemii, na podstawie których stwierdza się cukrzycę. Ponadto w bardzo istotny sposób ta sama grupa badana różnicuje natomiast wiedze badanych studentów o tym, że cukrzyca typu II stanowi minimum $90 \%$ przypadków wszystkich chorych na cukrzycę (Tabela 2).

Bardziej szczegółową wiedzę na temat wpływu środowiskowych czynników rozwoju cukrzycy posiadają osoby, które mają styczność z cukrzycą w rodzinie. Ponadto posiadanie w rodzinie osób z cukrzycą powoduje również wzrost wiedzy na temat czynników, które mogą działać prewencyjnie na wystąpienie cukrzycy typu II (Tabela 3).

Większość badanych zdaje sobie sprawę z tego, że istnieją różne sposoby terapii cukrzycy typu II i insulina nie jest jedynym preparatem stosowanym w tej chorobie, przy czym również ta wiedza jest w istotny sposób modyfikowana zmienną posiadania w rodzinie osób chorych na cukrzyce (Tabela 4).

Niezależnie od jakiejkolwiek zmiennej większość badanych studentów słyszała o tym, że w chwili obecnej mówi się o cukrzycy typu II jako o epidemii XXI wieku. Ponad połowa badanych nie posiada wiedzy na temat zależności występowania cukrzycy od wieku (Tabela 5).

Zdecydowanie spora grupa respondentów jest zdania, że w każdym przypadku leczenie cukrzycy typu II obejmuje dietę, zaś według podobnej grupy zmianę trybu życia i leczenie farmakologiczne. Taki sam odsetek badanych za ważny element leczenia cukrzycy uznaje leczenie farmakologiczne. W gronie badanych połowa studentów nie wie, czy kobiety z cukrzycą typu II mogą korzystać z terapii hormonalnej. Taki sam odsetek badanych uważa, że konieczne są w tej sprawie konsultacje z diabetykiem (Tabela 6).

Wśród ankietowanych najbardziej znane powikłania cukrzycy to: retinopatia, nefropatia i zespół stopy cukrzycowej. O takich powikłaniach wie 98\% badanych studentów pielęgniarstwa. Ponadto 75\% uważa, że częstym powikłaniem cukrzycy jest także uczucie drętwienia i bólu kończyn. Zdecydowana większość respondentów uważa, że dla cukrzyków wskazane jest spożywanie ciemnego pieczywa (92\%) i warzyw (96\%). $72 \%$ badanych uważa, że wskazane są również owoce. $21 \%$ badanych jest zdania, iż ważną rolę w diecie cukrzycowej pełni nabiał i przetwory mleczne.

W gronie osób badanych 34\% uważa, że glikemia na czczo wyższa niż 100 mg/dl jest wskazaniem do wykonania doustnego testu tolerancji glukozy. Zdecydowana większość badanych jest zdania, że takim wskazaniem jest dopiero wystąpienie cech zespołu metabolicznego (nawet jeśli glikemia na czczo jest prawidłowa). Ponadto zdecydowana większość badanych studentów uważa, że powodem hiperglikemii może być posiłek zbyt bogaty w węglowodany, zaś podobna grupa respondentów za istotną przyczynę hiperglikemii uważa podanie zbyt małej dawki insuliny (Tabela 7). 
Tabela 2. Wiedza respondentów na temat cukrzycy typu II, z podziałem na osoby z przypadkami i bez przypadków cukrzycy w rodzinie Table 2. Knowledge of T2DM among study participants by persons with and without the family history of diabetes

\begin{tabular}{|c|c|c|c|c|c|c|c|c|}
\hline \multirow[t]{2}{*}{$\begin{array}{l}\text { Pytanie/ } \\
\text { Question }\end{array}$} & \multirow[t]{2}{*}{ Odpowiedź/Answer } & \multicolumn{6}{|c|}{$\begin{array}{cc}\text { Osoby z przy- } & \text { Osoby bez przy- } \\
\text { padkami cukrzy- } & \text { padków cukrzycy } \\
\text { cy w rodzinie/ } & \text { w rodzinie/ } \\
\text { Persons with } & \text { Persons without } \\
\text { family history of } & \text { family history of } \\
\text { diabetes } & \text { diabetes }\end{array}$} & \multirow[t]{2}{*}{$\mathrm{p}$} \\
\hline & & $\mathrm{n}$ & $\%$ & $\mathrm{n}$ & $\%$ & $\mathrm{n}$ & $\%$ & \\
\hline \multirow{5}{*}{$\begin{array}{c}\text { Cukrzyca typu II } \\
\text { jest chorobą: } \\
\text { Type } 2 \text { diabetes mellitus is }\end{array}$} & autoimmunologiczną/autoimmune disease & 4 & 3,96 & 0 & 0 & 3 & 4,00 & \multirow{5}{*}{$<0,005$} \\
\hline & idiopatyczną/idiopathic disease & 2 & 1,98 & 1 & 3,85 & 1 & 1,33 & \\
\hline & metaboliczną/metabolic disease & 87 & 86,14 & 25 & 96,15 & 63 & 84,00 & \\
\hline & powikłaniem innej choroby/complication of another disease & 6 & 5,94 & 0 & 0 & 6 & 8,00 & \\
\hline & nie wiem/l do not know & 2 & 1,98 & 0 & 0 & 2 & 2,67 & \\
\hline \multirow{3}{*}{$\begin{array}{l}\text { Czy cukrzyca typu Il stanowi } \\
\text { co najmniej } 90 \% \text { przypad- } \\
\text { ków chorych na cukrzycę?/ } \\
\text { Does T2DM account for at } \\
\text { least } 90 \% \text { of all cases of } \\
\text { patients with diabetes? }\end{array}$} & tak/yes & 44 & 43,56 & 21 & 80,77 & 23 & 30,67 & \multirow{3}{*}{$<0,005$} \\
\hline & nie/no & 33 & 32,68 & 2 & 7,69 & 31 & 41,33 & \\
\hline & nie wiem/l do not know & 24 & 23,76 & 3 & 11,54 & 21 & 28 & \\
\hline \multirow{4}{*}{$\begin{array}{l}\text { Czy cukrzyca typu II stanowi } \\
\text { podstawę do ograniczenia } \\
\text { aktywności zawodowej } \\
\text { i społecznej?/ } \\
\text { Does T2DM constitute } \\
\text { grounds to limit professional } \\
\text { and social activity? }\end{array}$} & $\begin{array}{l}\text { tak, chory na cukrzycę powinien starać się o rentę i ograniczyć swoją } \\
\text { aktywność życiową/yes, patients with diabetes should make a claim } \\
\text { for a pension and limit their life activity }\end{array}$ & 0 & 0 & 0 & 0 & 0 & 0 & \multirow{4}{*}{$<0,005$} \\
\hline & $\begin{array}{l}\text { chory na cukrzycę powinnien ograniczyć swoją aktywność tylko } \\
\text { w kilku uzasadnionych przypadkach (np. zawodowy kierowca w przy- } \\
\text { padku zagrożenia hipoglikemią)/patients with diabetes should limit } \\
\text { their life activity only in a few well justified cases (e.g. a professional } \\
\text { driver with the risk of hypoglycaemia) } \\
\text { nie ma potrzeby ograniczania swojej aktywności w tej chorobie/ } \\
\text { there is no need to limit life activity }\end{array}$ & 14 & 13,86 & 16 & 61,54 & 21 & 9,33 & \\
\hline & nie wiem// do not know & 50 & 49,5 & 3 & 11,54 & 47 & 62,67 & \\
\hline & inne/other & 0 & 0 & 0 & 0 & 0 & 0 & \\
\hline \multirow{11}{*}{$\begin{array}{c}\text { Jaki wpływ na organizm } \\
\text { osoby chorej na cukrzyce } \\
\text { typu II ma spożycie alkoho- } \\
\text { lu?/How does alcohol affect } \\
\text { the body of a person with } \\
\text { T2DM? }\end{array}$} & hipoglikemia/hypoglycaemia & 67 & 66,34 & 18 & 69,23 & 49 & 65,33 & \multirow{11}{*}{$<0,005$} \\
\hline & kwasica ketonowa/diabetic ketoacidosis & 13 & 12,87 & 2 & 7,69 & 11 & 14,67 & \\
\hline & wzrost ciśnienia tętniczego/increased blood pressure & 27 & 26,73 & 2 & 7,69 & 25 & 33,33 & \\
\hline & $\begin{array}{l}\text { uszkodzenie serca, wątroby i trzustki/damage to the heart, liver and } \\
\text { pancreas }\end{array}$ & 41 & 40,59 & 3 & 11,54 & 38 & 50,67 & \\
\hline & otyłość/obesity & 3 & 2,97 & 1 & 3,85 & 2 & 2,67 & \\
\hline & zwiększa ryzyko miażdżycylincreased risk of atherosclerosis & 16 & 15,84 & 2 & 7,69 & 14 & 18,67 & \\
\hline & zwiększa ryzyko udaru mózgu/increased risk of stroke & 28 & 27,72 & 3 & 11,54 & 25 & 33,33 & \\
\hline & zwiększa ryzyko zawału serca/increased risk of myocardial infarction & 16 & 15,84 & 3 & 11,54 & 13 & 17,33 & \\
\hline & inne/other & 0 & 0 & 0 & 0 & 0 & 0 & \\
\hline & $\begin{array}{c}\text { spożycie alkoholu nie ma wpływu innego na organizm cukrzyka niż } \\
\text { na osobę zdrową/influence of alcohol consumption on a diabetic } \\
\text { person and a healthy one is the same }\end{array}$ & 11 & 10,89 & 9 & 34,62 & 2 & 2,67 & \\
\hline & nie wiem/l do not know & 8 & 7,92 & 1 & 3,85 & 7 & 9,33 & \\
\hline \multirow{8}{*}{$\begin{array}{c}\text { Jaki wpływ na organizm } \\
\text { osoby chorej na cukrzyce } \\
\text { typu II ma palenie tytoniu?/ } \\
\text { How does smoking affect } \\
\text { the body of a person with } \\
\text { T2DM? }\end{array}$} & hipoglikemia/hypoglycaemia & 2 & 1,98 & 0 & 0 & 2 & 2,67 & \multirow{8}{*}{$<0,005$} \\
\hline & kwasica ketonowa / diabetic ketoacidosis & 1 & 0,99 & 0 & 0 & 1 & 1,33 & \\
\hline & $\begin{array}{l}\text { wzrost ciśnienia tętniczego/ } \\
\text { increased blood pressure }\end{array}$ & 59 & 58,42 & 4 & 15,38 & 55 & 73,33 & \\
\hline & $\begin{array}{l}\text { uszkodzenie serca, wątroby i trzustki/damage to the heart, liver and } \\
\text { pancreas }\end{array}$ & 16 & 15,84 & 2 & 7,69 & 14 & 18,67 & \\
\hline & otyłość/obesity & 0 & 0 & 0 & 0 & 0 & 0 & \\
\hline & inne/other & 0 & 0 & 0 & 0 & 0 & 0 & \\
\hline & $\begin{array}{c}\text { palenie nie ma wpływu innego na organizm cukrzyka niż na osobę } \\
\text { zdrową/smoking has the same impact on diabetics and healthy } \\
\text { persons }\end{array}$ & 41 & 40,59 & 19 & 73,08 & 22 & 28,33 & \\
\hline & nie wiem/l do not know & 23 & 22,77 & 4 & 15,38 & 19 & 25,33 & \\
\hline \multirow{6}{*}{$\begin{array}{l}\text { Nieprawidłowa glikemia } \\
\text { na czczo i nieprawidłowa } \\
\text { tolerancja glukozy to/ } \\
\text { Impaired fasting glucose } \\
\text { and impaired glucose toler- } \\
\text { ance are }\end{array}$} & stan przedcukrzycowy/ prediabetes & 17 & 16,83 & 9 & 34,62 & 8 & 10,67 & \multirow{6}{*}{$<0,005$} \\
\hline & $\begin{array}{l}\text { jednostka kliniczna (cukrzyca) w każdym przypadku/clinical entity } \\
\text { (diabetes) in each case }\end{array}$ & 35 & $\begin{array}{c}34,65 / \\
34.65\end{array}$ & 2 & $\begin{array}{l}7,69 / \\
7.69\end{array}$ & 33 & 44 & \\
\hline & $\begin{array}{c}\text { jednostka kliniczna (cukrzyca), jeśli pacjentka jest w ciąży/clinical } \\
\text { entity (diabetes) if a patient is pregnant }\end{array}$ & 15 & 14,85 & 3 & 11,54 & 12 & 16 & \\
\hline & czynnik ryzyka przyszłej cukrzycy/risk factor of future diabetes & 41 & 40,59 & 22 & 84,62 & 19 & 25,33 & \\
\hline & inne/other & 0 & 0 & 0 & 0 & 0 & 0 & \\
\hline & nie wiem/l do not know & 14 & 13,86 & 3 & 11,54 & 11 & 14,67 & \\
\hline
\end{tabular}




\begin{tabular}{|c|c|c|c|c|c|c|c|c|}
\hline $\begin{array}{l}\text { Cukrzyca typu Il stanowi co } \\
\text { najmniej } 90 \% \text { przypadków }\end{array}$ & tak/yes & 44 & 43,56 & 21 & 80,77 & 23 & 30,67 & \\
\hline $\begin{array}{c}\text { chorych na cukrzyce/Does } \\
\text { T2DM account for at least }\end{array}$ & nie/no & 33 & 32,68 & 2 & 7,69 & 31 & 41,33 & $<0,005$ \\
\hline $90 \%$ of all cases of patients & & & & & & & & \\
\hline with diabetes? & nie wiem// do not know & 24 & 23,76 & 3 & 11,54 & 21 & 28 & \\
\hline
\end{tabular}

Źródło: opracowanie własne

Source: author's own analysis

Tabela 3. Wiedza studentów pielęgniarstwa na temat czynników i objawów cukrzycy typu Il, z podziałem na osoby z przypadkami i bez przypadków cukrzycy w rodzinie

Table 3. Knowledge of factors and manifestations of T2DM among Nursing students by persons with and without the family history of diabetes

\begin{tabular}{|c|c|c|c|c|c|c|c|c|}
\hline \multirow[t]{2}{*}{$\begin{array}{l}\text { Pytanie/ } \\
\text { Question }\end{array}$} & \multirow[t]{2}{*}{ Odpowiedź/Answer } & \multicolumn{2}{|c|}{$\begin{array}{l}\text { Ogółem/ } \\
\text { Total }\end{array}$} & \multicolumn{2}{|c|}{$\begin{array}{l}\text { Osoby z przypadkami } \\
\text { cukrzycy w rodzinie/ } \\
\text { Persons with the family } \\
\text { history of diabetes }\end{array}$} & \multicolumn{2}{|c|}{$\begin{array}{l}\text { Osoby bez przypad- } \\
\text { ków cukrzycy } \\
\text { w rodzinie/ } \\
\text { Persons without the } \\
\text { family history of dia- } \\
\text { betes }\end{array}$} & \multirow[t]{2}{*}{$p$} \\
\hline & & $\mathrm{n}$ & $\%$ & $\mathrm{n}$ & $\%$ & $\mathrm{n}$ & $\%$ & \\
\hline \multirow{8}{*}{$\begin{array}{l}\text { Jakie czynniki środowi- } \\
\text { skowe mają największe } \\
\text { znaczenie w powstawaniu } \\
\text { cukrzycy typu II?/Which } \\
\text { environmental factors are } \\
\text { most significant for the } \\
\text { development of T2DM? }\end{array}$} & infekcje wirusowe/viral infections & 2 & 1,98 & 0 & 0 & 2 & 2,67 & \multirow{8}{*}{$<0,05$} \\
\hline & niedobór witaminy $D_{3}$ vitamin D3 deficiency & 1 & 0,99 & 0 & 0 & 1 & 1,33 & \\
\hline & $\begin{array}{c}\text { zbyt wczesne wprowadzenie białek do diety } \\
\text { w okresie wczesnego dzieciństwa/ } \\
\text { proteins introduced too early to the diet in early } \\
\text { childhood }\end{array}$ & 0 & 0 & 0 & 0 & 0 & 0 & \\
\hline & $\begin{array}{c}\text { zbyt duże spożycie konserwantów, barwników } \\
\text { i innych dodatków do żywności/too much con- } \\
\text { sumption of preservatives, colourings, and other } \\
\text { food additives }\end{array}$ & 36 & 35,64 & 4 & 15,38 & 32 & 42,67 & \\
\hline & otyłość/obesity & 91 & 90,10 & 26 & 100 & 65 & 86,67 & \\
\hline & $\begin{array}{l}\text { zbyt siedzący tryb życia/ } \\
\text { too much of a sedentary lifestyle }\end{array}$ & 54 & 53,47 & 23 & 88,46 & 31 & 41,33 & \\
\hline & stres/stress & 37 & 36,53 & 12 & 46,15 & 25 & 33,33 & \\
\hline & nie wiem/l do not know & 1 & 0,99 & 0 & 0 & 1 & 1,33 & \\
\hline \multirow{9}{*}{$\begin{array}{l}\text { Jakie czynniki mogą wpły- } \\
\text { wać prewencyjnie na wystą- } \\
\text { pienie cukrzycy typu II?/ } \\
\text { Which factors may prevent } \\
\text { T2DM? }\end{array}$} & $\begin{array}{l}\text { zwiększona aktywność fizycznalincreased physi- } \\
\text { cal activity }\end{array}$ & 81 & 80,2 & 24 & 92,3 & 57 & 76 & \multirow{9}{*}{$<0,005$} \\
\hline & niższe spożycie cukru/lower sugar intake & 47 & 46,53 & 17 & 65,38 & 30 & 4 & \\
\hline & $\begin{array}{l}\text { niższe spożycie kalorii// } \\
\text { lower calorie intake }\end{array}$ & 48 & 47,52 & 19 & 73,08 & 29 & 38,67 & \\
\hline & odchudzanie/slimming & 13 & 12,87 & 7 & 26,92 & 6 & 8 & \\
\hline & $\begin{array}{c}\text { badania prewencyjne z zastosowanym później } \\
\text { prewencyjnym leczeniem farmakologicznym/ } \\
\text { preventive check-ups followed by preventive } \\
\text { pharmacotherapy }\end{array}$ & 12 & 11,88 & 6 & 23,08 & 6 & 8 & \\
\hline & $\begin{array}{c}\text { badania prewencyjne z późniejszą zmianą stylu } \\
\text { życia/preventive check-ups followed by changes } \\
\text { in lifestyles }\end{array}$ & 48 & 47,52 & 21 & 80,77 & 27 & 36 & \\
\hline & $\begin{array}{c}\text { prewencyjne stosowanie diety cukrzycowej/ } \\
\text { preventive diabetic diet }\end{array}$ & 18 & 17,82 & 2 & 7,69 & 16 & 21,33 & \\
\hline & inne/other & 0 & 0 & 0 & 0 & 0 & 0 & \\
\hline & nie wiem// do not know & 2 & 1,98 & 0 & 0 & 2 & 2,67 & \\
\hline \multirow{13}{*}{$\begin{array}{l}\text { Jakie objawy wskazują } \\
\text { na możliwość rozwoju } \\
\text { cukrzycy?/ } \\
\text { What is indicative of devel- } \\
\quad \text { oping diabetes? }\end{array}$} & zmniejszenie masy ciała/weight loss & 31 & 30,69 & 6 & 23,08 & 25 & 33,33 & \multirow{13}{*}{ NS } \\
\hline & zwiększenie masy ciała/weight gain & 64 & 63,37 & 23 & 88,46 & 41 & 54,67 & \\
\hline & brak łaknienia/loss of appetite & 16 & 15,84 & 3 & 11,54 & 13 & 17,33 & \\
\hline & wzmożone pragnienie/polydipsia & 91 & 90,1 & 25 & 96.15 & 66 & 88 & \\
\hline & skąpomocz/oliguria & 17 & 16,83 & 3 & 11,54 & 14 & 18,67 & \\
\hline & wielomocz/polyuria & 65 & 64,36 & 24 & 92,31 & 41 & 54,67 & \\
\hline & osłabienie/weakness & 52 & 51,49 & 14 & 53,85 & 38 & 50,67 & \\
\hline & senność/somnolence & 78 & 77,23 & 25 & 96,15 & 53 & 70,67 & \\
\hline & $\begin{array}{c}\text { pojawienie się zmian ropnych na skórze/ } \\
\text { purulent lesions on the skin } \\
\text { pojawienie się stanów zapalnych narządów }\end{array}$ & 40 & 39,6 & 5 & 19,23 & 35 & 46,67 & \\
\hline & $\begin{array}{l}\text { moczowo-płciowych/ } \\
\text { genitourinary inflammation }\end{array}$ & 31 & 30,69 & 5 & 19,23 & 26 & 34,67 & \\
\hline & $\begin{array}{l}\text { zwiększona podatność na choroby wirusowe/ } \\
\text { increased susceptibility to viral diseases }\end{array}$ & 16 & 15,84 & 3 & 11,54 & 13 & 17,33 & \\
\hline & inne/other & 0 & 0 & 0 & 0 & 0 & 0 & \\
\hline & nie wiem/l do not know & 0 & 0 & 0 & 0 & 0 & 0 & \\
\hline
\end{tabular}




\begin{tabular}{|c|c|c|c|c|c|c|c|c|}
\hline & pragnienie/thirst & 83 & 82,18 & 25 & 96,15 & 58 & 77,33 & \multirow{11}{*}{ NS } \\
\hline Jakie objawy mogą wystą- & wielomocz/polyuria & 67 & 66,34 & 19 & 73,08 & 48 & 64 & \\
\hline pić u chorego na cukrzycę & skąpomocz/oliguria & 9 & 8,91 & 1 & 3,85 & 8 & 10,67 & \\
\hline typu II w momencie nad- & suchość w jamie ustnej/dry mouth & 76 & 75,25 & 19 & 73,08 & 57 & 76 & \\
\hline miernego wzrostu cukru & brak apetytu/loss of appetite & 62 & 61,39 & 13 & 50 & 49 & 65,33 & \\
\hline we krwi?/ & bóle brzucha/abdominal pain & 51 & 50,5 & 7 & 26,92 & 44 & 58,67 & \\
\hline \multirow{5}{*}{$\begin{array}{l}\text { What symptoms may occur } \\
\text { in patients with T2DM at } \\
\text { the moment of increased } \\
\text { blood sugar levels? }\end{array}$} & nudności i wymioty/nausea and vomiting & 53 & 52,48 & 7 & 26,92 & 46 & 61,33 & \\
\hline & senność/somnolence & 88 & 87,13 & 26 & 100 & 62 & 82,67 & \\
\hline & nadmierny apetyt/excessive appetite & 43 & 42,57 & 7 & 26,92 & 36 & 48 & \\
\hline & inne/other & 0 & 0 & 0 & 0 & 0 & 0 & \\
\hline & nie wiem/l do not know & 4 & 3,96 & 0 & 0 & 4 & 5,33 & \\
\hline & picie solonych płynów/drink salty liquids & 0 & 0 & 0 & 0 & 0 & 0 & \multirow{9}{*}{ NS } \\
\hline & $\begin{array}{l}\text { sprawdzenie zawartości cukru i acetonu w moczu/ } \\
\text { check sugar and acetone levels in urine }\end{array}$ & 62 & 61,39 & 19 & 73,08 & 43 & 57,33 & \\
\hline & $\begin{array}{l}\text { wstrzykniecie dodatkowej dawki insuliny o szyb- } \\
\text { kim działaniu/inject an additional dose of fast- } \\
\text { acting insulin }\end{array}$ & 85 & 84,16 & 24 & 92,31 & 61 & 81,33 & \\
\hline $\begin{array}{l}\text { Jakie jest postępowanie } \\
\text { w przypadku objawów } \\
\text { hiperglikemii? }\end{array}$ & $\begin{array}{l}\text { wstrzykniecie dodatkowej dawki insuliny o długo- } \\
\text { trwałym działaniu/ } \\
\text { inject an additional dose of long-acting insulin }\end{array}$ & 0 & 0 & 0 & 0 & 0 & 0 & \\
\hline \multirow[t]{5}{*}{$\begin{array}{l}\text { What are emergency proce- } \\
\text { dures in hyperglycaemia? }\end{array}$} & $\begin{array}{l}\text { natychmiastowy kontakt z lekarzem/contact your } \\
\text { doctor immediately }\end{array}$ & 0 & 0 & 0 & 0 & 0 & 0 & \\
\hline & $\begin{array}{c}\text { wezwanie karetki pogotowia/ } \\
\text { call an ambulance }\end{array}$ & 4 & 3,96 & 1 & 3,85 & 3 & 4 & \\
\hline & zjedzenie czegoś słodkiego/eat something sweet & 6 & 5,94 & 3 & 11,54 & 3 & 4 & \\
\hline & inne/other & 0 & 0 & 0 & 0 & 0 & 0 & \\
\hline & nie wiem// do not know & 12 & 11,88 & 2 & 7,69 & 10 & 13,33 & \\
\hline
\end{tabular}

Źródło: opracowanie własne

Source: author's own analysis

Tabela 4. Poziom wiedzy ankietowanych dotycząca leczenia cukrzycy typu II, z podziałem na osoby z przypadkami i bez przypadków cukrzycy w rodzinie Table 4. Knowledge of T2DM management among study participants by persons with and without family history of diabetes

\begin{tabular}{|c|c|c|c|c|c|c|c|c|}
\hline \multirow{2}{*}{\multicolumn{2}{|c|}{ Pytanie/Question }} & \multicolumn{2}{|c|}{ Ogółem/Total } & \multicolumn{4}{|c|}{$\begin{array}{l}\text { Osoby z przypad- Osoby bez przy- } \\
\text { kami cukrzycy padków cukrzycy } \\
\text { w rodzinie/ } \quad \text { w rodzinie/ } \\
\text { Persons with the Persons without } \\
\text { family history of the family history of } \\
\text { diabetes diabetes }\end{array}$} & \multirow[t]{2}{*}{$\mathrm{p}$} \\
\hline & & $\mathrm{n}$ & $\%$ & $n$ & $\%$ & $\mathrm{n}$ & $\%$ & \\
\hline \multirow{9}{*}{$\begin{array}{l}\text { Kiedy w cukrzycy typu II } \\
\text { wprowadza się leczenie } \\
\text { insuliną?/When is insulin } \\
\text { initiated in T2DM? }\end{array}$} & $\begin{array}{l}\text { zawsze w przypadku rozpoznania cukrzycy/always after diabe- } \\
\text { tes diagnosis }\end{array}$ & 8 & 7,92 & 0 & 0 & 8 & 10,67 & \multirow{9}{*}{$<0,01$} \\
\hline & $\begin{array}{c}\text { zawsze przy glikemii powyżej } 300 \mathrm{mg} / \mathrm{dl} / \text { always with glycaemia } \\
\text { over } 300 \mathrm{mg} / \mathrm{dl}\end{array}$ & 16 & 15,84 & 1 & 3,85 & 15 & 20 & \\
\hline & $\begin{array}{l}\text { przy glikemii około } 300 \mathrm{mg} / \mathrm{dl} \text { wraz z współistniejącymi objawa- } \\
\text { mi klinicznymi cukrzycy/with glycaemia of approximately } 300 \mathrm{mg} / \\
\text { dl and coexisting clinical signs of diabetes }\end{array}$ & 12 & 11,88 & 6 & 23,08 & 6 & 8 & \\
\hline & zawsze przy długotrwałej cukrzycy/always in long-lasting diabetes & 1 & 0,99 & 0 & 0 & 1 & 1,33 & \\
\hline & $\begin{array}{l}\text { w ciąży, niezależnie od wartości glikemii/in pregnant women } \\
\text { irrespective of blood glucose levels }\end{array}$ & 4 & 3,96 & 3 & 11,54 & 1 & 1,33 & \\
\hline & $\begin{array}{l}\text { w ciąży, przy glikemii powyżej } 100 \mathrm{mg} / \mathrm{dl} / \text { in pregnant women } \\
\text { with glycaemia over } 100 \mathrm{mg} / \mathrm{dl}\end{array}$ & 1 & 0,99 & 1 & 3,85 & 0 & 0 & \\
\hline & zawsze w cukrzycy typu LADA/always in LADA patients & 0 & 0 & 0 & 0 & 0 & 0 & \\
\hline & na życzenie pacjenta chorego na cukrzycę/on request of a diabetic & 0 & 0 & 0 & 0 & 0 & 0 & \\
\hline & $\begin{array}{c}\text { w przypadku braku skuteczności leków doustnych/when oral } \\
\text { medication is inefficient }\end{array}$ & 47 & 46,53 & 13 & 50 & 34 & 45,33 & \\
\hline \multirow{2}{*}{$\begin{array}{l}\text { Preparaty insulinowe są } \\
\text { jedynym sposobem lecze- } \\
\text { nia cukrzycy typu II:/Insulin } \\
\text { is the only treatment of } \\
\text { T2DM: }\end{array}$} & $\begin{array}{l}\text { preparaty insulinowe są jedynym sposobem leczenia/insulin is } \\
\text { the only treatment }\end{array}$ & 8 & 7,92 & 1 & 3,85 & 7 & 9,33 & \multirow[b]{2}{*}{$<0,05$} \\
\hline & $\begin{array}{l}\text { preparaty insulinowe nie są jedynym sposobem leczenia/insulin } \\
\text { is not the only treatment }\end{array}$ & 79 & 78,22 & 25 & 96,15 & 54 & 72 & \\
\hline \multirow{2}{*}{$\begin{array}{l}\text { Podstawę leczenia cukrzy- } \\
\text { cy stanowi odpowiednia } \\
\text { dieta/an adequate diet is } \\
\text { most important in treat- } \\
\text { ment of diabetes } \\
\end{array}$} & $\begin{array}{l}\text { preparaty insulinowe są jedynym sposobem leczenia/insulin is } \\
\text { the only treatment }\end{array}$ & 84 & 83,17 & 25 & 96,15 & 59 & 78,67 & \multirow[b]{2}{*}{ NS } \\
\hline & $\begin{array}{l}\text { preparaty insulinowe nie są jedynym sposobem leczenia/insulin } \\
\text { is not the only treatment }\end{array}$ & 1 & 0,99 & 0 & 0 & 1 & 1,33 & \\
\hline
\end{tabular}

Źródło: opracowanie własne

Source: author's own analysis 
Tabela 5. Wiedza respondentów na temat cukrzycy typu II

Table 5. Knowledge of T2DM among study participants

\begin{tabular}{|c|c|c|}
\hline Pytanie/Question & Odpowiedź/Answer & $\begin{array}{l}\text { Procent udzielonych } \\
\quad \text { odpowiedzi \%/ } \\
\text { Percent of answers \% } \\
\end{array}$ \\
\hline \multirow{2}{*}{$\begin{array}{l}\text { Cukrzyca typu II jest chorobą/Type } 2 \text { diabetes } \\
\text { mellitus is }\end{array}$} & insulinozależną/insulin-dependent & 34 \\
\hline & insulinoniezależną/non-insulin-dependent & 53 \\
\hline \multirow{3}{*}{$\begin{array}{l}\text { Jak często należy u osób zdrowych powyżej } 45 \\
\text { roku życia przeprowadzać badanie prewencyjne } \\
\text { w kierunku cukrzycy?/ } \\
\text { How often should healthy adults over } 45 \text { years of } \\
\text { age undergo a check-up for diabetes? }\end{array}$} & raz w roku/once a year & 94 \\
\hline & raz na dwa lata/once every two years & 1 \\
\hline & raz na trzy lata/once every three years & 2 \\
\hline \multirow{14}{*}{$\begin{array}{l}\text { U jakich osób, niezależnie od wieku, należy } \\
\text { co roku przeprowadzać badanie w kierunku } \\
\text { cukrzycy? } \\
\text { (pytanie wielokrotnego wyboru)/ } \\
\text { Who, regardless of age, should undergo a test } \\
\text { for diabetes every year? } \\
\text { (multiple-choice question) }\end{array}$} & u osób z nadwagą (BMl $\left.\geqslant 25 \mathrm{~kg} / \mathrm{m}^{2}\right) /$ overweight persons $\left(B M \mathrm{l} \geqslant 25 \mathrm{~kg} / \mathrm{m}^{2}\right)$ & 90,09 \\
\hline & $\begin{array}{c}\text { u osób, których rodzice lub rodzeństwo chorują na cukrzycę/persons whose parents or } \\
\text { siblings have diabetes }\end{array}$ & 36,14 \\
\hline & $\begin{array}{l}\text { u osób spożywających znaczne ilości węglowodanów/persons consuming large amounts } \\
\text { of carbohydrates }\end{array}$ & 8,91 \\
\hline & $\begin{array}{l}\text { u osób mało aktywnych fizycznie/ } \\
\text { persons with low physical activity }\end{array}$ & 25,74 \\
\hline & $\begin{array}{l}\text { u osób, u których w poprzednim badaniu stwierdzono nieprawidłową glikemię na czczo } \\
\text { lub nietolerancję glukozy/persons with abnormal fasting blood glucose or intolerance of } \\
\text { glucose in the last test }\end{array}$ & 90,09 \\
\hline & $\begin{array}{l}\text { u kobiet, które przebyły cukrzycę ciążowa/women with a history of gestational diabetes } \\
\text { mellitus }\end{array}$ & 52,48 \\
\hline & u osób z nadciśnieniem tętniczym/persons with hypertension & 28,71 \\
\hline & u osób z niskim ciśnieniem/ persons with low blood pressure & 2,97 \\
\hline & u osób z hiperlipidemią/persons with hyperlipidemia & 44,55 \\
\hline & u osób apatycznych/apathetic persons & 7,92 \\
\hline & u osób z chorobą układu sercowo-naczyniowego/persons with a cardiovascular disease & 10,89 \\
\hline & $\begin{array}{c}\text { osób młodych pomiędzy } 20 \text { a } 40 \text { rokiem życia/young persons between } 20 \text { and } 40 \text { years of } \\
\text { age }\end{array}$ & 8 \\
\hline & u osób powyżej 65 roku życia/persons over 65 years of age & 12 \\
\hline & $\begin{array}{l}\text { cukrzyca jest zupełnie niezależna od wieku i występuje w każdej grupie wiekowej w po- } \\
\text { dobnym procencie/it is entirely independent of the age and occurs in every age group with } \\
\text { similar percentage }\end{array}$ & 16 \\
\hline \multirow{12}{*}{$\begin{array}{c}\text { Na podanej liście proszę zaznaczyć wszystkie } \\
\text { znane Państwu czynniki ryzyka rozwoju cukrzy- } \\
\text { cy typu Il: } \\
\text { (pytanie wielokrotnego wyboru)/ } \\
\text { Please indicate all risk factors for T2DM that are } \\
\text { known to you: } \\
\text { (multiple-choice question) }\end{array}$} & nadwaga/overweight & 100 \\
\hline & $\begin{array}{l}\text { pokrewieństwo z osobami chorymi na cukrzyce (rodzice, rodzeństwo)/family relationship } \\
\text { with diabetics (parents, siblings) }\end{array}$ & 85,15 \\
\hline & niska aktywność fizyczna/low physical activity & 81,19 \\
\hline & $\begin{array}{l}\text { nieprawidłowa glikemia na czczo stwierdzona w badaniu kontrolnym/impaired fasting } \\
\text { glycaemia in a follow-up examination }\end{array}$ & 67,33 \\
\hline & przebycie cukrzycy ciężarnych/history of gestational diabetes mellitus & 50,50 \\
\hline & $\begin{array}{l}\text { urodzenie dziecka o wadze powyżej } 4 \mathrm{~kg} / \text { women who have had } \\
\text { a baby over } 4 \mathrm{~kg}\end{array}$ & 36,63 \\
\hline & $\begin{array}{l}\text { urodzenie dziecka o wadze poniżej } 2 \mathrm{~kg} / \text { women who have had } \\
\qquad \text { a baby under } 2 \mathrm{~kg}\end{array}$ & 2,97 \\
\hline & nadciśnienie tętnicze/hypertension & 46,53 \\
\hline & hiperlipidemia/hyperlipidemia & 42,57 \\
\hline & zespół policystycznych jajników/polycystic ovary syndrome & 12,87 \\
\hline & choroba układu sercowo-naczyniowego/cardiovascular disease & 16,83 \\
\hline & problemy gastryczne (biegunki, zgaga itp.)/gastric problems (diarrhoea, heartburn, etc.) & 4,95 \\
\hline
\end{tabular}

Źródło: opracowanie własne

Source: author's own analysis 
Tabela 6. Poziom wiedzy ankietowanych na temat leczenia cukrzycy typu II Table 6. Knowledge of treatment of T2DM among study participants

\begin{tabular}{|c|c|c|}
\hline Pytanie/Question & Odpowiedź/Answer & $\begin{array}{l}\text { Procent udzielonych } \\
\text { odpowiedzi \% / } \\
\text { Percent of answers \% }\end{array}$ \\
\hline \multirow{3}{*}{$\begin{array}{l}\text { Leczenie cukrzycy typu ll obejmuje: } \\
\text { (pytanie wielokrotnego wyboru)/ } \\
\text { Treatment of T2DM include: } \\
\text { (multiple-choice question) }\end{array}$} & $\begin{array}{c}\text { zmianę diety/change in diet } \\
\text { zmianę stylu życia/change in lifestyle }\end{array}$ & $\begin{array}{l}98,02 \\
88,12\end{array}$ \\
\hline & leczenie farmakologiczne/pharmacotherapy & 88,12 \\
\hline & jest to zależne od podłoża chorobylit depends on the background of the disease & 2,97 \\
\hline \multirow{4}{*}{$\begin{array}{l}\text { Jakie są wskazania do czasowej insulinoterapii u chorych } \\
\text { na cukrzyce?? } \\
\text { (pytanie wielokrotnego wyboru)/ } \\
\text { What are the indications for short-term insulin therapy in diabetics? } \\
\text { (multiple-choice question) }\end{array}$} & $\begin{array}{c}\text { nie ma czasowej insulinoterapii, kto już zacznie brać insulinę bierze } \\
\text { ją do końca życia/there is no short-term insulin therapy, if you start } \\
\text { taking insulin, it is for life }\end{array}$ & 5 \\
\hline & zabieg chirurgiczny/surgical procedure & 23 \\
\hline & udar mózgu/stroke & 18 \\
\hline & ostry zespół wieńcowy/acute coronary syndrome & 21 \\
\hline \multirow{3}{*}{$\begin{array}{l}\text { Czy kobieta chora na cukrzycę typu II może stosować doustne środki } \\
\text { hormonalne?/ } \\
\text { Can a woman with T2DM take oral contraceptives? }\end{array}$} & $\begin{array}{l}\text { tak, jeśli nie pali tytoniu i nie ma więcej niż } 30 \text { lat/yes, if she does not } \\
\text { smoke and is below } 30 \text { years old }\end{array}$ & 4 \\
\hline & $\begin{array}{l}\text { tylko po konsultacji z diabetykiem, o ile nie ma żadnych przeciwwskazań/ } \\
\text { only after consultation of diabetologist,, unless contraindicated }\end{array}$ & 48 \\
\hline & absolutnie nie/absolutely not & 0 \\
\hline \multirow{3}{*}{$\begin{array}{l}\text { Czy ważną rolę w leczeniu cukrzycy odgrywa dietetyk?/ } \\
\text { Does a dietician play an important role in treatment of diabetes? }\end{array}$} & tak/yes & 98 \\
\hline & nie/no & 0 \\
\hline & nie wiem/l do not know & 2 \\
\hline \multirow{5}{*}{$\begin{array}{l}\text { Jaki rodzaj leczenia stosuje się w cukrzycy typu II?/ } \\
\text { What kind of treatment is used for T2DM? }\end{array}$} & insulinę/insulin & 0 \\
\hline & insulinę i dietę/insulin and diet & 36 \\
\hline & wyłącznie dietę/only insulin & 0 \\
\hline & tabletki/tablets & 5 \\
\hline & insulinę i tabletki/insulin and tablets & 11 \\
\hline \multirow{5}{*}{$\begin{array}{l}\text { W jakie miejsca wstrzykuje się insulinę? } \\
\text { (pytanie wielokrotnego wyboru)/ } \\
\text { What are the sites of insulin injection?/ } \\
\text { (multiple-choice question) }\end{array}$} & środkowa część ramienia/the middle part of the arm & 92,08 \\
\hline & okolice brzucha/abdomen area & 95,05 \\
\hline & uda/thighs & 88,12 \\
\hline & pośladki/buttocks & 20,79 \\
\hline & pod topatką/under the scapula & 33,66 \\
\hline
\end{tabular}

Źródło: opracowanie własne

Source: author's own analysis

Tabela 7. Wiedza studentów pielęgniarstwa na temat testu tolerancji glukozy, hiperglikemii oraz hipoglikemii Table 7. Knowledge of the glucose tolerance test, hyperglycaemia and hypoglycaemia among Nursing students

\begin{tabular}{|c|c|c|}
\hline Pytanie/Question & Odpowiedź/Answer & $\begin{array}{l}\text { Procent udzielonych } \\
\text { odpowiedzi \%/ } \\
\text { Percent } \\
\text { of answers \% }\end{array}$ \\
\hline \multirow{6}{*}{$\begin{array}{c}\text { Jakie są wskazania do wykonania doustnego testu toleran- } \\
\text { cji glukozy? (pytanie wielokrotnego wyboru) /What are the } \\
\text { indications for the oral glucaose tolerance test? (multiple- } \\
\text { choice question) }\end{array}$} & $\begin{array}{c}\text { cechy zespołu metabolicznego przy prawidłowej glikemii na czczo/symptoms of } \\
\text { metabolic syndrome with normal fasting glucose }\end{array}$ & 73,27 \\
\hline & glikemia na czczo poniżej 80 mg/dl/fasting glucose levels below 80 mg/dl & 2,97 \\
\hline & glikemia na czczo powyżej 100 mg/dl/fasting glucose levels over 100 mg/dl & 34,64 \\
\hline & glikozuria przy prawidłowej glikemii na czczo/glycosuria with normal fasting glucose & 18,81 \\
\hline & ciąża zagrożona/high-risk pregnancy & 1,98 \\
\hline & każda ciąża/every pregnancy & 13,86 \\
\hline \multirow{3}{*}{$\begin{array}{c}\text { Przyczyną hiperglikemii w cukrzycy typu II jest Państwa } \\
\text { zdaniem: (pytanie wielokrotnego wyboru)/In your opinion, } \\
\text { what is the cause of hyperglycaemia in T2DM? (multiple- } \\
\text { choice question) }\end{array}$} & zbyt mała dawka insuliny/too small dose of insulin & 80,20 \\
\hline & zbyt niski poziom aktywności fizycznej/too little physical activity & 67,33 \\
\hline & $\begin{array}{l}\text { posiłek za bardzo bogaty w wegglowodany/ a diet too rich in carbohydrates } \\
\text { infekcja wirusowa lub inna choroba/viral infection or another disease }\end{array}$ & $\begin{array}{l}92,08 \\
45,54\end{array}$ \\
\hline \multirow{6}{*}{$\begin{array}{c}\text { Przyczyną hipoglikemii w cukrzycy typu II jest Państwa } \\
\text { zdaniem: (pytanie wielokrotnego wyboru)/In your opinion, } \\
\text { what is the cause of hypoglycaemia in T2DM? (multiple- } \\
\text { choice question) }\end{array}$} & zbyt duża dawka insuliny/too high dose of insulin & $\begin{array}{l}4,54 \\
88,12\end{array}$ \\
\hline & zbyt duży poziom aktywności fizycznej/too much physical activity & 72,28 \\
\hline & $\begin{array}{l}\text { zbyt mały posiłek lub jego brak po insulinie/too small snack or no snack after } \\
\text { insulin injection }\end{array}$ & 92,08 \\
\hline & spożycie alkoholu/alcohol consumption & 38,61 \\
\hline & infekcja wirusowa lub inna choroba/viral infection or another disease & 15,84 \\
\hline & nieregularne przyjmowanie zaleconych tabletek/irregular use of tablets recommended & 32,67 \\
\hline \multirow{6}{*}{$\begin{array}{l}\text { Jakie jest postępowanie w przypadku objawów hipoglike- } \\
\text { mii? (pytanie wielokrotnego wyboru)/What to do in the event } \\
\text { of hypoglycaemia symptoms? (multiple-choice question) }\end{array}$} & $\begin{array}{l}\text { picie solonych płynów/drink salty liquids } \\
\text { picie słodzonych płynów/drink sweetened liquids } \\
\text { sprawdzenie zawartości cukru/check the sugar level }\end{array}$ & $\begin{array}{c}0 \\
72,28 \\
82,18\end{array}$ \\
\hline & $\begin{array}{c}\text { wstrzykniecie dodatkowej dawki insuliny o szybkim działaniu/inject an additional } \\
\text { dose of fast-acting insulin }\end{array}$ & 3,96 \\
\hline & natychmiastowy kontakt z lekarzem/contact your doctor immediately & 4,95 \\
\hline & & $\begin{array}{l}3,96 \\
40,59\end{array}$ \\
\hline & $\begin{array}{l}\text { zjedzenie czegoś słodkiego (baton, czekolada, ciastko)/eat something sweet } \\
\text { (a bar, chocolate, cake) }\end{array}$ & 58,42 \\
\hline & zjedzenie kanapki/have a sandwich & 2,97 \\
\hline
\end{tabular}

Źródło: opracowanie własne

Source: author's own analysis 


\section{Dyskusja}

Cukrzyca już od kilku lat nazywana jest epidemią XXI wieku. Szacuje się, że w Polsce chorych na tę chorobę jest około 2,6 miliona osób, co stanowi 5\% ogółu społeczeństwa. Na całym świecie ta liczba wzrasta do około 285 milionów osób. Co więcej, cukrzyca i towarzyszące jej powikłania stanowią jedną z pięciu najważniejszych przyczyn zgonów w krajach rozwiniętych [4]. Te liczby wskazują na to, iż w zawodzie pielęgniarki prawdopodobieństwo kontaktu z przypadkami cukrzycy u pacjentów jest bardzo wysokie. Tym samym bardzo ważny jest poziom wiedzy, jaki personel pielęgniarski posiada na temat tej choroby. Ponieważ coraz częściej za prawidłowy uznaje się holistyczny model opieki nad pacjentem [5], pielęgniarka musi posiadać wiedzę o chorobach cywilizacyjnych, takich jak cukrzyca, które mają wpływ na wszystkie aspekty zdrowia pacjenta. Tymczasem przeprowadzone badania pokazały bardzo niski poziom wiedzy studentów pielęgniarstwa na temat cukrzycy typu II.

Według przeprowadzonych badań wystarczający poziom wiedzy posiada duży odsetek studentów, jednakże niewielki odsetek studentów, ale również pielęgniarek (w tym praktykujących) uważa cukrzycę za powikłanie innej choroby, chorobę autoimmunologiczną czy idiopatyczną. Również autor raportu na temat ogólnej wiedzy społeczeństwa o cukrzycy typu II twierdzi, że Polacy posiadają niewystarczającą wiedzą na temat cukrzycy, a większość uważa, że jest to choroba, której nie można zapobiec [4]. Również badani studenci pielęgniarstwa w 29\% uważają, że cukrzyca jest chorobą o podłożu genetycznym, a 62\% respondentów jest zdania, że za jej rozwój w równym stopniu odpowiadają czynniki genetyczne i środowiskowe. Tymczasem, jak donosi Abramczyk [6], zdrowie osób z cukrzycą w dużym stopniu jest uzależnione od opartych na wiedzy i odpowiednim przygotowaniu zachowań pacjentów. Jak donoszą Kosicka i Wrońska, edukacja zdrowotna jest bardzo istotnym elementem leczenia cukrzycy, zaś w tej edukacji zasadniczą rolę odgrywa pielęgniarka, która ma najczęstszy kontakt z pacjentem i duże możliwości podejmowania działań edukacyjnych [7]. Również zdaniem Naszydłowskiej i in. [2] pielęgniarka stanowi najbardziej bezpośrednie źródło wiedzy dla pacjenta z cukrzycą. Edukacyjna rola pielęgniarki jest jedną z funkcji pielęgnowania i jednocześnie bardzo istotną formą opieki pielęgniarskiej. Na funkcję edukacyjną składa się wiele szczegółowych zadań, których celem jest przygotowanie pacjenta do samoopieki i samokontroli, a także systematyczne motywowanie pacjenta do działania na rzecz własnego zdrowia [8].

Z przeprowadzonych przez Kosicką i Wrońską [7] badań wynika, że pielęgniarka pełni główną rolę eduka- tora w cukrzycy. Przekazuje bowiem wiedzę z zakresu istoty cukrzycy, kontroli glikemii, aktywności fizycznej odżywiania, jak również kształtuje umiejętności związane z podawaniem insuliny. Optymalizacja masy ciała, ciśnienia tętniczego krwi, stężenia cholesterolu, glikemii, zapobieganie hipoglikemii, a więc czynniki zależne od decyzji i zachowania pacjenta [9] powodują, że zaleca się informowanie osób z cukrzycą nie tylko o celach leczenia, ale także o szczegółowych rezultatach, na które wskazują wyniki badań [6]. Wśród wielu pacjentów z cukrzyca jest obserwowany jednak brak znajomości wyników badań wskazujących na lepszy stan zdrowia [10]. Może to wynikać z tego, że jak pokazały badania własne, wiele pielęgniarek nie posiada dokładnej wiedzy na temat rozpoznawania cukrzycy typu II. Dla badanych pielęgniarek i pielęgniarzy nie jest również oczywista wiedza o prawidłowym poziomie glikemii na czczo. Tymczasem odmienna od zalecanej percepcja wyników badań i wskaźników zdrowia może być dla pacjentów źródłem problemów w stosowaniu zaleceń istotnych w leczeniu oraz modyfikacji stylu życia [11]. Deficyt w zakresie znajomości parametrów rozpoznawania cukrzycy typu II i konieczność edukacji społeczeństwa w tym zakresie potwierdziły wyniki badań prowadzonych w populacji ogólnej [4].

Zdaniem autora raportu dotyczącego znajomości informacji o cukrzycy w społeczeństwie [4] także świadomość konsekwencji wynikających z cukrzycy nie jest wystarczająca. 35\% Polaków nie potrafi wymienić ani jednego skutku choroby, pomimo że jest to schorzenie wielonarządowe, które charakteryzuje się szeregiem powikłań. Studenci pielęgniarstwa przewyższają w tym zakresie poziom wiedzy ogółu społeczeństwa. 98\% badanych wymieniło bowiem retinopatię, nefropatię oraz stopę cukrzycową jako znane im powikłania, $90 \%$ wskazało na zmiany skórne, $75 \%$ na drętwienie i ból kończyn, a tylko niespełna $2 \%$ nie potrafiło wymienić ani jednego objawu choroby.

Według ogólnopolskiego badania [4] ponad połowa Polaków nie wie, że ryzyko zachorowania na cukrzycę zwiększają otyłość i nadwaga. W grupie badanych studentów pielęgniarstwa taką wiedzę posiadali wszyscy badani. 85\% respondentów w badaniach własnych wskazało na czynniki genetyczne jako istotne podłoże choroby, podczas gdy w populacji ogólnopolskiej odsetek osób posiadających wiedzę na temat genetycznych skłonności do zachorowania wynosi tylko 38\% [4].

W leczeniu osób z cukrzycą zaleca się dążenie do modyfikacji i przejścia z siedzącego do bardziej aktywnego stylu życia, a wszystkie formy codziennej aktywności uznaje się za pomocne [12]. Mimo że regularna aktywność fizyczna sprzyja zmniejszeniu ryzyka chorób układu krążenia i niesprawności oraz stanowi istotny element w leczeniu cukrzycy, większość pacjentów 
z cukrzycą typu II nie uwzględnia jej jako stałego elementu w swoim stylu życia [6]. W przeprowadzonych przez NHANES IV (Fourth National Health and Nutrition Examination Survey) badaniach wśród pacjentów z cukrzycą typu II [13] wskazano, że większość chorych na cukrzycę nie uwzględnia zaleceń w zakresie aktywności fizycznej i charakteryzuje się jej brakiem (31\%) lub nieregularną aktywnością (38\%). Jedynie u 31\% pacjentów ustalono regularną aktywność fizyczną. W polskich badaniach prowadzonych przez Abramczyk [6] odsetek pacjentów respektujących zalecenia w zakresie aktywności fizycznej był niewiele mniejszy od uzyskanego w badaniach NHANES IV i wyniósł 38\%. Jak donoszą bowiem badacze [14,15] edukacja osób z cukrzycą odgrywa istotną rolę w procesie umacniania zdrowia i ochrony życia tej grupy chorych. Tymczasem nie wszyscy badani studenci pielęgniarstwa zdają sobie sprawę z prewencyjnego działania zwiększonej aktywności fizycznej u osób z grupy ryzyka zachorowania na cukrzycę, zaś niespełna połowa badanych widzi możliwość zapobiegania chorobie poprzez zmniejszenie spożycia cukru, zmniejszenie spożycia kalorii czy też poprzez regularne przeprowadzanie badań z jednoczesną zmianą stylu życia. Nic więc dziwnego, że w polskiej populacji nie więcej niż co czwarta osoba zdaje sobie sprawę, że do zachorowania na cukrzycę typu II może przyczynić się jedzenie potraw słodkich (25\%), lub tłustych (23\%) oraz zbyt mało aktywny tryb życia (20\%). W badaniach własnych tylko 53,5\% studentów pielęgniarstwa uważa zbyt siedzący tryb życia za czynnik rozwoju cukrzycy typu II, a zatem pozostałych 46,5\% nie będzie prowadzić skutecznej akcji edukacyjnej dotyczącej profilaktyki. Należy przy tym pamiętać, że wyniki wielu badań dowodzą, że cukrzyca rozwija się częściej u osóbsłabiejedukowanych [15]. Wiedzastanowibowiem niezbędny element leczenia, który pozwala pacjentom troszczyć się o siebie przy podejmowaniu codziennych czynności i ważnych z punktu ochrony zdrowia decyzji. Potwierdzeniem tego jak ważne jest edukowanie osób z cukrzycą, jest udzielenie przez rząd Stanów Zjednoczonych poparcia dla programu edukacji w cukrzycy i zagwarantowanie jego realizacji przez ponad 11 tysięcy akredytowanych wychowawców [6].

Mimo licznych korzyści będących efektem edukacji w cukrzycy [14], wyniki badań prowadzonych przez Ambramczyk [6] wskazują, że wielu chorych jej nie otrzymuje. Przeprowadzone wśród osób z cukrzycą badania potwierdziły niezadowalający stan edukacji, którego wyrazem jest znaczny deficyt wiedzy występujący u 95\% badanych pacjentów. Z pewnością nie pozostaje to bez związku z ustaloną w badaniach własnych niską wiedzą przyszłych (jak również obecnych) pielęgniarek. Wystarczy wspomnieć, że tylko 53\% badanych studen- tów pielęgniarstwa wie, że cukrzyca typu II jest chorobą insulinoniezależną, a 34\% jest przekonanych o tym, że jest to chorobą nierozerwalnie związana z podawaniem do końca życia insuliny. Niepokojący jest bardzo niski poziom wiedzy studentów pielęgniarstwa na temat wprowadzania insuliny w leczeniu cukrzycy typu II oraz momentu, w którym do leczenia cukrzycy typu II wprowadza się insulinę.

Sposób żywienia, uwarunkowany wpływem wielu czynników [16], stanowi nieodłączny element w leczeniu osób z cukrzycą. Sprostanie wymaganiom żywieniowym przysparza chorym wielu problemów [17]. Pacjenci z cukrzycą, ze względu na sytuację ekonomiczną, poziom edukacji, wsparcie czy też uwarunkowania kulturowe, nie są w stanie wielu zaleceń w pełni zastosować [6]. W prowadzonych wśród osób z cukrzycą badaniach wykazuje się, że tylko $60 \%$ pacjentów stosuje dietę [16]. Z badań NHANES IV [13] wynika natomiast, że zaleceń w zakresie żywienia nie stosuje ponad $60 \%$ osób z cukrzycą, u ponad $60 \%$ pacjentów ustalono deficyt w zakresie spożywania owoców i warzyw oraz nadmierne spożycie tłuszczów. Istotną rolę w edukacji żywieniowej pacjentów z cukrzycą mają do spełnienia pielęgniarki, tym bardziej iż badania własne pokazały, że wiedza na temat diety cukrzycowej jest w grupie studentów pielęgniarstwa stosunkowo wysoka.

Pacjenci z cukrzycą należą do tej grupy chorych, w której palenie tytoniu, poza tym że powoduje wzrost ryzyka powikłań, w wielu przypadkach jest przyczyną przedwczesnego zgonu [6]. Pomoc w zerwaniu z nałogiem palenia tytoniu uważana jest w przypadku osób z cukrzycą za jedno z najważniejszych działań o charakterze zapobiegawczym [16]. Jednak w gronie badanych studentów pielęgniarstwa aż 40\% respondentów uważa, że palenie nie ma na organizm pacjenta z cukrzycą wpływu większego niż w przypadku osoby zdrowej. Niepokojący jest przy tym wyższy odsetek badanych z taką opinią w grupie osób, które w rodzinie spotykają się z cukrzycą. Powoduje to, że pacjenci, z którymi mają styczność, mogą zostać błędnie poinformowani o braku bezpośredniego związku pomiędzy paleniem a rozwojem choroby i jej powikłań. Pomimo to z badań Abramczyk [6] wynika, że w grupie osób chorych na cukrzycę mniejszy jest odsetek osób palących w stosunku do danych ogólnopolskich. Korzystniejsza jednak względem populacji ogólnej sytuacja w zakresie palenia tytoniu u badanych osób z cukrzycą może być, zdaniem autorki, wyrazem prowadzonej edukacji zarówno w stosunku do ogółu społeczeństwa, jak i osób z cukrzycą [6].

W opiece nad pacjentem z cukrzycą zwraca się także uwagę na to, aby mimo dyskutowanych korzyści wynikających z umiarkowanego spożywania alkoholu 
[6] nie polecać tego rodzaju produktu w celach profilaktycznych [16]. Konsumpcja alkoholu jest bowiem uznawana za ważny wyznacznik przedwczesnej śmierci, zwłaszcza wśród mężczyzn i osób z niższych grup społeczno-ekonomicznych [18]. Z przeprowadzonych wśród osób z cukrzycą badań wynika, że 73\% chorych nie pije alkoholu i nie pali tytoniu, $6 \%$ badanych wskazuje na spożywanie alkoholu, 12\% deklaruje palenie tytoniu, a 8\% pacjentów pije alkohol i pali tytoń [6]. Generalnie większość badanych studentów pielęgniarstwa zdaje sobie sprawę z tego, że alkohol ma szkodliwy wływ na organizm osoby chorej na cukrzycę, choć $66 \%$ uważa, że ten szkodliwy wpływ wyraża się jedynie w hipoglikemii. Jednak ponad 34\% populacji studentów, u których w rodzinie stwierdzono przypadek cukrzycy, uważa, że alkohol nie ma większego wpływu na organizm osoby z cukrzycą niż na organizm osoby zdrowej.

Cukrzyca należy do chorób, w których wraz ze wzrostem zmian chorobowych, a także w wyniku wielu dolegliwości i wahań glikemii, dochodzi do ograniczeń w zakresie realizacji pełnionych ról społecznych i funkcjonowania w rodzinie i społeczeństwie [19]. Trudności w funkcjonowaniu społecznym pacjentów z cukrzycą mogą być także determinowane postawami osób w ich otoczeniu [20]. Badania w populacji ogólnopolskiej wykazały, że najczęściej osoby z cukrzycą nie uczestniczą w życiu zawodowym (84\%) i organizacjach społecznych (59\%). Co dziesiąty pacjent nie uczestniczy w życiu towarzyskim (13\%). Z całościowej analizy funkcjonowania społecznego osób z cukrzycą wynika, że żadnych trudności w funkcjonowaniu w analizowanych formach życia społecznego nie ma tylko 4\% badanych [6]. Niemal połowa badanych studentów pielęgniarstwa deklaruje brak wiedzy w zakresie aktywności zawodowej i społecznej osób chorych na cukrzycę, 36\% uważa, że osoby takie powinny ograniczyć swoją aktywność tylko w uzasadnionych koniecznością przypadkach, zaś 13\% jest zdania, że w tej chorobie można funkcjonować całkowicie normalnie.

W zawodzie pielęgniarki bardzo ważna jest umiejętność szybkiej reakcji w sytuacji zagrożenia życia i zdrowia pacjenta. Stan takiego zagrożenia powstaje niewątpliwie w hiperglikemii u pacjentów z cukrzycą. Badania pokazały jednak, że pielęgniarki nie znają w sposób dostateczny objawów hiperglikemii, a co za tym idzie nie potrafią prawidłowo reagować na taką sytuację. Nie wszyscy pielęgniarze i pielęgniarki sugerowaliby wstrzyknięcie dodatkowej dawki insuliny o szybkim działaniu, a niektórzy podaliby nawet pacjentowi coś słodkiego. $11 \%$ badanych otwarcie przyznaje, że zupełnie nie wie, jak reagować w takiej sytuacji. Nieco mniejszy problem mają studenci pielęgniarstwa $z$ rozpoznawaniem objawów hipoglikemii, przy czym zasadniczo wiedzą, co może ją wywoływać, choć nie zawsze wiedzą, jak pomóc pacjentowi w takiej sytuacji, bowiem niemal $4 \%$ badanej populacji byłaby skłonna wstrzyknąć pacjentowi dodatkową dawkę szybko działającej insuliny. Wyniki badań własnych wskazują zatem bezwzględnie na konieczność prowadzenia dalszych badań z zakresu wiedzy o cukrzycy w grupie pielęgniarek oraz studentów pielęgniarstwa, a także na konieczność prowadzenia intensywnych działań edukacyjnych w tej grupie zawodowej.

Liczne badania potwierdziły bowiem znaczącą poprawę w zakresie klinicznych wskaźników leczenia cukrzycy, edukacji i satysfakcji pacjentów, których opieką zarządzała pielęgniarka [6, 16, 19, 21, 22, 23]. Zasadne jest zatem rozważenie możliwości zorganizowania systematycznych szkoleń dla grupy personelu pielęgniarskiego z zakresu wiedzy o cukrzycy. Ważne jest bowiem podkreślenie, jak ważną rolę w poprawie jakości życia osób z cukrzycą, może odegrać pielęgniarka współpracująca ściśle z lekarzem i pacjentem. Uzyskanie pozytywnych efektów w opiece nad chorym z cukrzycą na każdym poziomie leczenia wymaga jednak, aby pielęgniarki posiadały przygotowanie do opieki nad tą grupą chorych - przygotowanie, które opierałoby się choćby na elementarnej wiedzy o tej chorobie, której to wiedzy wielu studentom, kończącym już edukację, brakuje.

\section{Wnioski}

1. Studenci pielęgniarstwa posiadają ogólną wiedzę o czynnikach ryzyka choroby, a także o znaczeniu diety i stylu życia w jej leczeniu, jednakże szczegółowy poziom wiedzy o cukrzycy jest niewystarczający do realizacji prawidłowej opieki i edukacji pacjentów z cukrzycą typu II.

2. Różnicująco na poziom wiedzy wpływa posiadanie w rodzinie osoby chorej na cukrzycę.

3. Zaznacza się wyraźna potrzeba zwiększenia edukacji na rzecz cukrzycy w grupie studentów pielęgniarstwa.

\section{Piśmiennictwo}

1. Brodawko B, Mosiewicz J, Czepło C. Przewlekłe powikłania cukrzycy i świadomość osób z cukrzycą odnosząca się do problemów ich choroby. Med Metab 2005; X (2): 90-94.

2. Naszydłowska E, Kozieł D, Trawczyńska M. Udział pielęgniarki w podnoszeniu jakości życia pacjentów z cukrzycą. Piel XXI w 2003; 3: 53-56.

3. Krzemińska S. Edukacja chorego na cukrzycę. Mag Piel i Położ 2006; 1-2: 30-31.

4. Sobierajski T. Wyniki badania „Społeczny obraz cukrzycy”. Raport. Koalicja na Rzecz Walki z Cukrzycą, Warszawa 2010.

5. Nosko J. Zachowania zdrowotne i zdrowie publiczne. Aspekty historyczno-kulturowe. Łódź: Instytut Medycyny Pracy im. Prof. J. Nofera; 2005.

6. Abramczyk A. Stan opieki nad chorym z cukrzycą w podstawowej opiece zdrowotnej a zapotrzebowanie na opiekę pielęgniarską. Wrocław: Akademia Medyczna; 2007.

7. Kosicka B, Wrońska I. Rola pielęgniarki w edukacji chorych na cukrzycę. Probl Piel 2007; 15 (2): 187-191. 
8. Ciechanowicz W. Działalność pedagogiczna pielęgniarki. Warszawa: PZWL; 2004.

9. Borodako A. Klasyfikacja i rozpoznanie cukrzycy. Terapia 2007; 5: 3-9.

10. Czech A. Epidemiologia i etiologiczna klasyfikacja cukrzycy. Med Dydakt Wychow 2004; 36 (2): 11-17.

11. Bernas M. Kryteria i metody rozpoznawania cukrzycy ukierunkowane na zapobieganie powikłaniom. Med Metabol 2005; 9 (2): 32-44.

12. Tatoń J. Taktyka skoordynowanej prewencji cukrzycy typu 2 i miażdżycy. Przew Lek 2004; 4: 111-121.

13. Nelson K. M., Reiber G., Boyko E. J. Diet and exercise among adults with type 2 diabetes. Findings from the Fourth National Health and Nutrition Examination Survey (NHANES IV). Diabetes Care 2007; 25: 1722-1728.

14. Otto-Buczkowska E. Edukacja chorych na cukrzycę ze szczególnym uwzględnieniem cukrzycy typu 2. Lekarz 2002; 4: 16-78.

15. Maciąg D, Knap M. Edukacja pacjenta z cukrzycą. Pol Med Rodz 2004; 6: 133-138.

16. Ponikowska I, Adamczyk P. Znaczenie aktywności fizycznej w leczeniu cukrzycy, W: Cukrzyca. Tom 1. Sieradzki J (red.). Gdańsk: Via Medica; 2006.

17. Szostak W. B. Otyłość - problem o rosnącym znaczeniu na przełomie wieków. Med Dypl 2005; 3/4: 7-11.

18. Joslin. Clinical nutrition guideline for overweight and obese adults with type 2 Diabetes, prediabetes or at high risk for developing type 2 diabetes. www.joslin.org_ (data dostępu 24.11.2014)

19. Kawalec P, Plic A. Koszty pośrednie cukrzycy w Polsce. Diabetol Prakt 2006; 7: 211-215.
20. Zahorska-Markiewicz B. Otyłość - współczesna diagnoza, W: Zespół metaboliczny, A. Mamcarz (red.). Warszawa: eMKa; 2008. 37-43.

21. Tatoń J, Szczeklik-Kumala Z, Czech A. Leczenie insuliną: wskazania i kryteria decyzji o rozpoczęciu insulinoterapii, monitoring. Standardy, algorytmy, sprzęt do wstrzykiwania, rola samokontroli. Przew Lek 2004; 4: 81-97.

22. Tatoń J, Czech A. Intensywne leczenie cukrzycy typu 2. Rekomendacje dla lekarzy praktyków. Warszawa: PZWL; 2004.

23. Wildin RS, Ramsdell F, Peake J. X-linked neonatal diabetes mellitus, enteropathy and endocrinopathy syndrome is the human equivalent of mouse scurfy. Nature Genetics 2007 27: 18-20.

Artykuł przyjęty do redakcji: 07.05.2016

Artykuł przyjęty do publikacji: 11.08.2016

Źródło finansowania: Praca nie jest finansowana z żadnego źródła. Konflikt interesów: Autorzy deklarują brak konfliktu interesów.

Adres do korespondencji:

Joanna Gotlib

ul. Żwirki i Wigury 61

02-091 Warszawa

tel.: 225720 490, fax: 225720491

e-mail: joanna.gotlib@wum.edu.pl

Zakład Dydaktyki i Efektów Kształcenia

Warszawski Uniwersytet Medyczny 